\title{
Video Reflexive Ethnography as a Tool for Better Classroom Practice
}

\section{Paul Stone}

Nippon Medical School

\begin{abstract}
This article describes an application of ethnographically-informed approaches to discourse analysis that attempts to bring about change in EFL classroom practice. The project was conducted by a teacher-researcher at a Japanese university and one group of learners that he taught. It centres on the use of video as a tool to bring about discussions between the teacher and learners that help them to better understand both their own classroom behaviour and each other's. The paper discusses the insights that such a project can bring as well as some problems inherent in conducting a project of this kind. This is not intended to be a paper that describes best practice, but is intended to outline a way in which teachers and learners can work together as co-researchers to better understand what they do in the classroom as a basis for improving classroom practice.
\end{abstract}

本論ではEFL授業での実践に変化をもたらすために、民族学的アプロ 一チを伴う談話分析を適用する試みについて記述する。このプロジェクト は日本の大学教師である研究者が行い、授業を担当している学生の 1 グ ループを対象とした。ビデオをツールとして使用し、教師と学生の間に議 論をうながすことで、相互間と学生個々の授業中の行動習慣の両方をよ り良く理解できるようにする。また、このようなプロジェクトがもたらしう る洞察及びこのようなプロジェクトに内在する問題について議論する。本 論は成功事例 (ベストプラクティス) の記述を目的とするのではなく、授 業内での実践を向上させるための土台として、学生達の教室内の行動を より良く理解するために、教師と学生が共同研究者として協働する方法の アウトラインを記述することを意図する。

$\mathrm{T}$ here is currently much interest in using video to help improve educational practice (Lefstein \& Snell, 2014). This article draws on ethnographically-informed research into discourse that uses video playback methodology to involve participants in the research process as co-researchers. The article's aim is to show that teachers can utilize such practices to promote teacher-learner dialogue that provides new understandings of what happens in the classroom, with the ultimate aim of improving classroom practice.

\section{Background}

Video has for some time been used to provide teachers with feedback and promote reflection (see Tripp \& Rich, 2012). This feedback has often come from teachers and administrators, but it is also important to take into account students' perceptions
(Murphey, 1993). This article discusses the use of video to promote teacher-student discussions and include students' perceptions in a process of reflection on classroom practice.

The project reported on here makes use of video-reflexive ethnography (e.g., ledema \& Carroll, 2014), a methodology that involves the researcher video-recording people doing things and then watching these videos back in discussion sessions with the participants. This allows the participants to become involved in the research process and to better understand their own behaviour. Video-reflexive ethnography is used to bring about change in institutions. For example, ledema and Carroll (2014) have used this methodology to help healthcare professionals better understand their work practices and subsequently change these practices for the better.

My project also borrows from Ron and Suzie Scollon's use of ethnographic methods in their discourse analysis research (e.g., Scollon, 2001; Scollon \& Scollon, 2001, 2004). Their approach similarly allows participants to take an active role in the research process. Of particular importance here is their use of what they call observer's interactions with members, or what Norris (2011, p. 58) calls contested data. This contested data involves video playback sessions where the observer takes his or her observations back to the group about which they were made. Through this process, it is possible for both the observers and the members of the group to come to understandings of the video data together.

While my project was actually a study of learner identity, a major aim of the project was to use reflexive video (or contested data) in order to facilitate teacher-learner discussions and affect change in the classroom. It is this aspect of the project that I am primarily concerned with here.

\section{Data/Method}

The project discussed here is a study of one Japanese university EFL class of 15 students. The project was explained clearly to all the students in the first class of the year and they were free to participate or not. All students chose to participate. Adapting the method for video-reflexive ethnography described in Carroll et al. (2008), the project can be divided into 
three phases: (1) observations of students performing classroom tasks and informal interviews with students to identify issues, (2) video recording of classroom interactions for more detailed analysis and material to use in video sessions, and (3) the video sessions themselves.

The observations and interviews performed in phase (1) served as a first stage of noticing that raised issues for further investigation. As well as the observations and interviews, I also asked students to compose short pieces of writing about their experiences in the classroom and I used these to help identify issues as well. For example, one problem raised was the common occurrence of silence in student discussions.

These issues were then investigated further with detailed analysis of the video recordings of classroom interactions in phase (2). As my interest was in how identities and learning are performed in classroom actions, I asked the following questions to guide my video analysis: "What actions are being performed?", "What identities/roles are being performed?" and "What learning is happening?".

For example, in investigating the issue of student silence, I looked at the different actions that silence was used to perform, the classroom roles students performed when they were silent, and how silence helped or hindered learning.

Through the initial observations I made in phase (1) and the more detailed video analysis of phase (2), I identified problems that I would like to discuss with the students in phase (3). I selected a video (usually about five-ten minutes long) for each student to watch in class, giving them three or four questions to think about as they watched the video. These varied according to the video but included general questions (e.g., "What is happening here?") and other questions that more specifically addressed the problems I had identified in phases (1) and (2).

Once the students had made their observations, I invited them to take part in small-group discussions with each other and myself. This happened in the classroom once a month throughout the semester (three times in total). Students who showed a particular interest in the project asked for extra lunchtime discussions on five occasions. In these discussions, which lasted from 20-30 minutes in the classroom and up to an hour outside of the classroom, we watched the video together and discussed our interpretations of what was happening. The sessions were semi-structured with the use of the same questions given to the students when they originally watched the video.
I also gave students opportunities to make comments that did not address the questions I had asked, so they could raise issues that I had not identified. The aim of these sessions was to facilitate a discussion between the students and teacher and bring about new ways of seeing classroom practices for all participants. That is, the project was not intended to just provide the teacher with feedback, but to initiate discourse between the teacher and students.

Table 1 gives an overview of the data collected for this project.

Table 1. Overview of data

\begin{tabular}{ll}
\hline Type of data & Details \\
\hline $\begin{array}{l}\text { Video } \\
\text { recordings }\end{array}$ & $\begin{array}{l}\text { I recorded } 28 \text { hours of natural- } \\
\text { ly-occurring student-student inter- } \\
\text { actions and classroom discussions, } \\
\text { once-a-week over one semester }\end{array}$ \\
$\begin{array}{l}\text { Audio } \\
\text { recordings }\end{array}$ & $\begin{array}{l}\text { I made 10 hours of recordings of } \\
\text { video-playback sessions, as well } \\
\text { as four hours of semi-structured } \\
\text { interviews with students }\end{array}$ \\
Field notes & $\begin{array}{l}\text { I made observations during each } \\
\text { class and wrote these up in a note- } \\
\text { book at the end of the class. My } \\
\text { informal interviews with students } \\
\text { that could not be captured as audio } \\
\text { recordings were also written up in } \\
\text { the notebook. }\end{array}$ \\
$\begin{array}{l}\text { Student } \\
\text { writing }\end{array}$ & $\begin{array}{l}\text { I asked students to compose short } \\
\text { pieces of writing about their } \\
\text { English language learning and } \\
\text { classroom experiences }\end{array}$ \\
\hline
\end{tabular}

\section{Findings}

This was an exploratory project and as such it brought to light a great variety of insights that might otherwise have remained hidden. Through conducting this project I was, for example, able to come to a new understanding of my own classroom behaviour and how my behaviour sometimes contradicted my beliefs. To give an example, while 1 believe in encouraging students to be independent thinkers and to not simply accept what their teachers say, I could see in the data that I often spoke over students, told them what to do and imposed my point of view on them. I will briefly describe some of the other insights provided by this project (Appendix 1 gives an overview of the major insights of the project). 


\section{Silence and turn-taking}

Silence is commonly observed in Japanese classrooms (e.g., Nakane, 2003) and as a teacher I have sometimes been frustrated that once I have set up an activity the room has plunged into silence. Why was it that students, who were mostly highly motivated and enthusiastic about their studies, often did not seem to fully engage in classroom activities?

It became clear that a major source of student silence was the negotiation of who should take the first turn at the start of a task when I had not specified how students should manage their interactions. Students claimed that they were sometimes confused as to how to conduct group discussions in the classroom, as they had little experience of doing this previously. So once I had asked them to start the activity they were sometimes at a loss as to how to proceed.

Many students said that they were reluctant to assume leadership and begin an activity unilaterally, and this was one reason why a number of activities began with a period of silence. The person who should speak first, and the subsequent order of turns, needed to be negotiated by the group prior to the actual activity starting, and this was often done nonverbally (and sometimes in Japanese). The video sessions brought this to light and allowed us to discuss ways in which to change these practices.

\section{Different focus of teacher and students}

The project brought to light the ways in which the students and myself were often working to different aims when performing interactions in the classroom. This could be seen clearly in small-group activities or pair-work where students often ignored my instructions. In spite of the teacher being in a more powerful position in the classroom, students do not always follow his or her instructions. So, while the teacher has an idea of how classroom interactions should unfold, what actually happens may differ significantly from what they had envisaged. Sometimes this may be because students do not understand instructions, or it may be an act of resistance, but frequently in the data collected for this class it was because the teacher and the students had different aims, which were related to different ideas about good, or normal, educational practice.

When setting up small-group activities my main aim was often to give students opportunities to practice using the L2 together. However, the students were often more focused on task completion or producing a neat and accurate record of work. For example, one activity required students to produce a short written text in pairs. I asked them to do this by communicating in English. The goal of the task (as I saw it) was to practice working together to solve problems in English, rather than produce a piece of writing per se. However, the video data revealed that the students worked together almost exclusively in Japanese with the only English words they used being those that they wrote in their notebooks (or nominated as candidates to be written in the notebook, but subsequently rejected). That is, the interactions were in Japanese, and English was treated as an object to be talked about, rather than the medium of interaction.

At several moments in the videos I stopped the activity to remind the students of the goal (i.e., to communicate in English). However, although the students clearly heard me they continued to communicate in Japanese. It is unlikely that this was only due to the students' English ability, as when I visited each group to talk to them they were able to communicate with me about the task in English.

When I brought this observation to the students in the video sessions it became clear that they were prioritizing doing the work of writing an accurate text. So, while my aim had been to focus on the process of producing the text, the students were focused on the written product. For them, it was easier to make this product by communicating in Japanese rather than English, and so the activity was not helping to achieve what I had set out to do.

In the video sessions, many students expressed surprise that I was not so concerned with the written product, but more with the quality of their spoken interactions. This allowed them to better understand my aims, but also allowed me to better understand the students and what was important for them.

\section{Correctness}

A closely related insight was that almost all students expressed a concern with being "correct" and leaving a neat and precise record of their work. That is, they were concerned that their English should be "correct" and that their written work should be done in a "correct" manner. Each student in the class brought with them a set of classroom materials that included pencils and erasers, and it was noticeable in the videos that they spent a lot of time erasing mistakes from their notebooks. At times, they withdrew from interactions or missed important information from the teacher as they erased or made notes in their book.

When I discussed this with the students a number of them explained that it was a regular part of their high school classroom practice to produce neat and 
accurate work and to use a mechanical pencil (so that they could correct mistakes), and that their high school teacher might criticize them if their work was untidy. Many students also said that they wanted to have tidy and correct notes to revise from or check in the future.

This concern with neatly copying "correct" information suggests that many students value learning what is correct. This could be clearly seen in one participant's comment that she liked grammar classes as there was a definite "correct answer." So, many students did not tolerate ambiguity or potential mistakes, which in turn constrained their ability to participate freely and learn from making mistakes.

It was noticeable that this concern with producing neat and accurate work extended to making rough notes on scrap paper (e.g., when brainstorming). Students often carefully made these 'rough' notes, meaning that an activity that I would ideally have liked to take just a minute or two could quite often take twice as long. This hindered the purpose of the brainstorming, which was to quickly come up with a variety of ideas. So, while I do not necessarily wish to encourage students to make "incorrect" or untidy notes, the slow and meticulous approach to producing correct and neat written work at all times was sometimes problematic for me.

\section{Discussion}

Through viewing the videos and the subsequent video discussion sessions it was possible to identify problems in the classroom, such as how the students and I were often working to different ideas of good educational practice. For example, while I was working to principles that stressed the importance of the process that students go through and the importance of interacting in the $\mathrm{L} 2$, the students were often working according to principles that stressed the importance of producing a "correct" product, with at times little or no importance given to actually communicating in English. Through taking part in the video sessions, the students were better able to understand my methodology and my reasons for doing certain activities, while I was better able to understand students' classroom behaviour.

In response to the insights brought about by this project I have attempted to change my classroom practice. For example, I think more carefully about setting up activities in relation to turn-taking (as well as teaching English phrases to help negotiate the beginning of activities) and I ask students to refrain from using erasers when brainstorming. I also try to avoid talking over students, as I had observed myself doing in the data. A number of the students commented that they have also tried to make changes to their own practices, and this has been noticeable in the classroom.

For example, one group of students were surprised when I explained that I saw their "conversational' interactions as being more successful than their 'formal' interactions (in which they took it in turns to express an opinion, but did not engage with one another's ideas, so that the interaction resembled mini-presentations). They had seen the more conversational interaction as inappropriate for the classroom. However, after the video session in which we discussed the learning potentials provided by conversation, as well as my beliefs about learning through interaction, this group had more dialogic discussions in the classroom and I could not find a subsequent example of them delivering their 'mini-presentations' to one another.

The greatest benefit of this project has been in bringing myself and my students into a dialogue about classroom practice that has allowed us to better understand one another and why we do what we do in the way we do it. This discussion and reflection have provided the basis for change.

Of course, a project of this kind brings challenges. First, it is time-consuming to record and watch all of the data, and a practicing teacher is unlikely to have time to collect and analyze the amount of data that I did. In addition, bringing observations of people's behaviour back to them can be threatening. Finally, some people do not like to be recorded. It is extremely important to be clear about the nature of the project from the beginning and to offer students the option of participating or not. However, I found the students in my class to be enthusiastic towards the project. It would also be feasible for many teachers to adapt the project to suit their everyday practices. The project would be much more manageable, for example, if teachers just focused on phase (3) and recorded activities that they then watched back in discussion with students.

I had expected language to be a problem in the video sessions. As expected, some of the students were not always able to express complex ideas clearly in English, or were not always able to completely understand my ideas. However, language proved to be less of a problem than I had anticipated and the video discussions proved to be very fruitful. The videos themselves provided a concrete focus to the discussions, which at times facilitated the communication of ideas that might have otherwise been more difficult to understand in the abstract. 


\section{Conclusion}

It is not the aim of this article to argue, for example, that either student silence or a focus on accuracy are in themselves good or bad. The article is instead focused on a way in which critical reflection on practice may help to promote dialogue and develop thoughtful students and teachers who can come to new understandings of their practice and make better-informed decisions about what they do together.

\section{References}

Carroll, K., ledema, R., \& Kerridge, R. (2008). Reshaping ICU ward round practices using video-reflexive ethnography. Qualitative Health Research, 18(3), 380-390.

Hauser, E. (2009). Turn-taking and primary speakership during a student discussion. In H. Nyugen \& G. Kasper. (Eds.) Talk-in-interaction: Multilingual perspectives (pp. 216-244). Hawaii: University of Hawaii.

ledema, R., \& Carroll, K. (2014). Intervening in health care communication using discourse analysis. In Flowerdew, J. (Ed.), Discourse in context: Contemporary applied linguistics 3 (pp. 185-204). London: Bloomsbury Academic.

Lefstein, A., \& Snell, J. (2014). Better than best practice: Developing teaching and learning through dialogue. Abingdon, Oxon: Routledge.

Murphey, T. (1993). Why don't teachers learn what learners learn? Taking the guesswork out with action logging. English Teaching Forum, 31(1), 6-10.

Nakane, I. (2003). Silence in Japanese-Australian classroom interaction: Perceptions and performance (Unpublished doctoral thesis). The University of Sydney, Sydney.

Norris, S. (2011). Identity in (inter)action: Introducing multimodal (inter)action analysis. Berlin: De Gruyter Mouton.

Scollon, R. (2001). Mediated discourse: The nexus of practice. Abingdon, Oxon: Routledge.

Scollon, R., \& Scollon, S. W. (2001). Intercultural communication (2nd ed.). Oxford: Blackwell.

Scollon, R., \& Scollon, S. W. (2004). Nexus analysis: Discourse and the emerging Internet. London: Routledge.

Tripp, T. R., \& Rich, P. J. (2012). The influence of video analysis on the process of teacher change. Teaching and Teacher Education, 28, pp. 728-739.

Paul Stone has been living and teaching English in Japan for about ten years, spending most of that time working in universities. He is currently a PhD candidate and his thesis focuses on the multimodal ways in which identities are produced in classroom interactions and how these identities affect opportunities for learning.

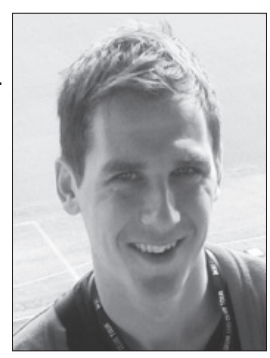

\section{Appendix}

\section{Major insights of the project}

- More conversational talk was seen towards the end of discussion tasks and at boundaries between tasks. This more conversational talk more accurately resembled the kind of talk the teacher was aiming for. While the teacher valued this, learners often thought it inappropriate for the classroom.

- Unfamiliarity with classroom roles expected by the teacher was a reason for student silence.

- The teacher and students had different ideas about what a "good student" and a "good teacher" should do in the classroom.

- Classroom materials (textbooks, CDs, etc.) provided students with examples of English-speaking identities and roles to copy when they performed classroom activities. While not necessarily finding the language content difficult in itself, some students did not feel comfortable performing the roles that were presented to them in the materials.

- The project revealed how certain participants required familiar student roles in order to motivate them to speak English in the classroom, while other participants were more motivated when speaking outside of these roles.

- Students oriented to "primary speaker" (see Hauser, 2009) turn-taking practices during group work, which was a major cause of student silence. The project uncovered reasons for this, how this affects learning opportunities, and how it is connected to identity issues.

\section{Call for Papers}

\section{JALT Niigata is now accepting proposals for presenters at the 8th Annual NEAR Language Education Conference.} Conference to be held on June 11, 2016 in Niigata City. For more information or to submit a proposal:

http://nearconference.weebly.com 